\title{
Chapter 41 \\ Screening for Genes Participating \\ in the Formation of Prismatic \\ and Nacreous Layers of the Japanese Pearl \\ Oyster Pinctada fucata by RNA \\ Interference Knockdown
}

\author{
Daisuke Funabara, Fumito Ohmori, Shigeharu Kinoshita, Kiyohito Nagai, \\ Kaoru Maeyama, Kikuhiko Okamoto, Satoshi Kanoh, Shuichi Asakawa, \\ and Shugo Watabe
}

\begin{abstract}
Many genes have been identified to participate in the shell formation so far. Nevertheless, the whole picture of the molecular mechanisms underlying the shell formation has remained unknown. In our previous study, we analyzed comprehensively genes expressed in the shell-producing tissues and identified 14 genes to be involved in the shell formation by the RNA interference (RNAi) method. In the present study, we performed further screening to find additional novel genes involved in the formation of the nacreous and prismatic layers. We here selected 80 genes from the EST data as candidates to function in the shell formation, conducted knockdown experiments by the RNAi method, and observed surface appearances on the nacreous and prismatic layers. We newly identified 64 genes that could participate in the shell formation. Taken together with our previous study, 78 genes were
\end{abstract}

D. Funabara $(\bowtie) \cdot$ S. Kanoh

Graduate School of Bioresources, Mie University, Tsu, Mie, Japan

e-mail: funabara@bio.mie-u.ac.jp; kanoh@bio.mie-u.ac.jp

F. Ohmori · K. Maeyama · K. Okamoto

MIKIMOTO COSMETICS, Mie, Japan

e-mail: oomori.353@mikimoto-cosme.com; maeyama.511@mikimoto-cosme.com;

okamoto.632@mikimoto-cosme.com

S. Kinoshita $\cdot$ S. Asakawa

Department of Aquatic Bioscience, Graduate School of Agricultural and Life Sciences,

The University of Tokyo, Tokyo, Japan

e-mail: akino@mail.ecc.u-tokyo.ac.jp; asakawa@mail.ecc.u-tokyo.ac.jp

K. Nagai

Pearl Research Laboratory, K. MIKIMOTO \& CO., LTD., Hamajima, Shima, Mie, Japan

S. Watabe

School of Marine Biosciences, Kitasato University, Minami, Sagamihara, Kanagawa, Japan

e-mail: swatabe@kitasato-u.ac.jp 
supposed to function in the shell formation. These findings indicate that the combination of transcriptome and knockdown analyses is a powerful tool to screen novel genes involved in the shell formation.

Keywords EST $\cdot$ Knockdown · Nacreous layer · Pearl oyster · Prismatic layer · RNAi $\cdot$ Shell

\subsection{Introduction}

Many genes have been identified to participate in the shell formation so far. In classical ways, proteins were purified from shells after decalcification and their properties were analyzed. Nacrein, for instance, was purified from shells of the Japanese pearl oyster Pinctada fucata and characterized in detail (Miyamoto et al. 1996). Suzuki et al. (2009) employed the RNA interference (RNAi) method to elucidate possible functions of Pif discovered as an aragonite-binding protein in the shell of P. fucata. Knockdown of the Pif gene by the RNAi method induced an abnormal crystal structure of aragonite. This finding confirmed that Pif is really involved in the nacreous layer formation and proved that the RNAi method is useful to study genes involved in shell formation. We obtained the EST data of nacreous and prismatic layer-producing tissues of $P$. fucata, which contained 29,682 genes, and found novel 29,550 genes (Kinoshita et al. 2011). Genes involved in the shell formation must be contained in these genes. Thus, we compared gene expression patterns among mantle pallium, edge, and pearl sac tissues using the EST data to find genes expressed in a tissue-specific manner. We selected five genes specifically expressed in the mantle pallium, three highly expressed in the mantle pallium and pearl sac, and six specifically expressed in the mantle edge as candidates to function in shell formation. Knockdown experiments for these candidate genes induced abnormal appearances on the inner surface of the shells in the oysters (Funabara et al. 2014). These findings demonstrated that a combination of transcriptome analyses and RNAi knockdown is a powerful tool to screen genes involved in the shell formation. In the present study, we conducted further screening for genes involved in the shell formation of P. fucata using the above method.

\subsection{Materials and Methods}

We selected 195 genes having more than 200 reads from the EST data (Kinoshita et al. 2011) of the shell-forming tissues, along with 9 genes expressed similarly to those known to be involved in the shell formation from genes having less than 200 reads in the EST data. We conducted cDNA cloning of the selected genes with primers designed using the nucleotide sequences of respective genes. dsRNAs of the selected genes were synthesized using the cDNA clones as templates with a ScriptMAX ${ }^{\mathrm{TM}}$ Thermo T7 Transcription Kit (Toyobo, Osaka, Japan). About $40 \mu \mathrm{g}$ of dsRNA/100 $\mu \mathrm{l} \mathrm{H}_{2} \mathrm{O}$ were injected into adductor muscles of 2-year-old pearl 
oysters $(n=3)$, followed by rearing them in artificial seawater at $23{ }^{\circ} \mathrm{C}$ for 8 days with feeding plankton once a day. The green fluorescence protein (GFP) and Pif genes were used as negative and positive references, respectively, to verify the RNAi experiments. Surface appearances of the prismatic and nacreous layers on the shells of the knockdown oysters were observed with a scanning electron microscope (SEM), S-4000 (Hitachi, Tokyo, Japan).

\subsection{Results}

\subsubsection{Selection of Candidate Genes Functioning in Shell Formation}

We selected candidate genes having more than 200 reads in the EST data (Kinoshita et al. 2011) to be possibly involved in the shell formation, except for 14 genes which we analyzed in our previous study (Funabara et al. 2014) (Table 41.1). cDNAs of 71 genes out of the selected 181 genes above were successfully cloned and used for synthesizing dsRNAs as templates. We selected additionally 9 genes showing expression patterns similarly to those of known shell formation-related genes such as PFMG1, KRMP1, N19, and N16 series from those having less than 200 reads (Table 41.1). cDNAs of all the nine genes were cloned and used for the synthesis of dsRNAs. A total of 80 genes were subjected to the knockdown experiments.

\subsubsection{Observation of the Appearances on the Inner Surface of the Knockdown Oyster Shells}

Knockdown of 64 out of 80 genes induced abnormal appearances on the inner surface of the shells (Table 41.2). Among them, 18 knockdown oysters had abnormal appearances on both the prismatic and nacreous layers, 45 only on the nacreous layers, and 1 only on the prismatic layers. The data combined with our previous study are shown in Fig. 41.1. Ninety-four genes, 80 in the present and 14 in our previous studies, contained 78 genes that are suggested to be involved in the shell formation processes. Only one gene changed the surface appearance on the prismatic layer.

\subsection{Discussion}

We have obtained the data of gene expression patterns and genes possibly involved in shell formation (Tables 41.1 and 41.2). It is not easy to discuss how genes play roles in shell formation based on expression patterns in the EST and knockdown data. We have only short sequences of the respective genes in the EST data. Fulllength sequences or at least open reading frame (ORF) regions of the interest genes 


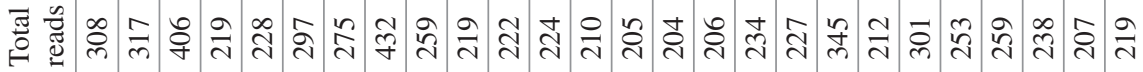

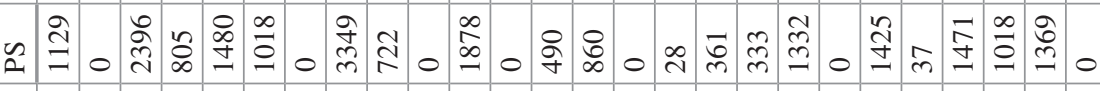

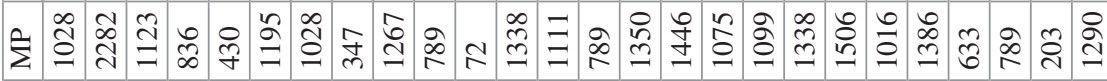

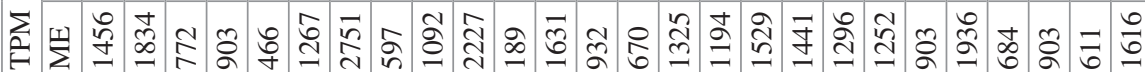

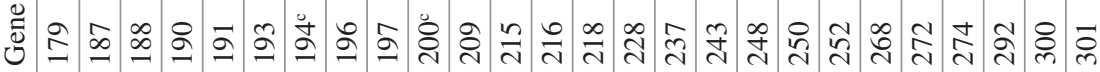

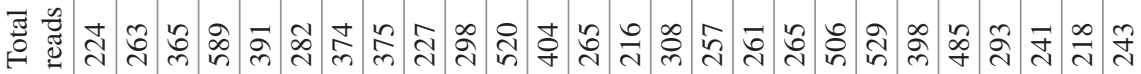

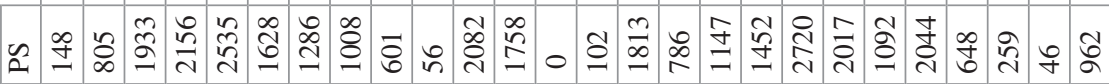

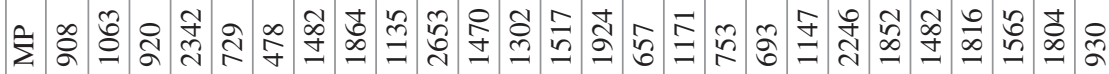

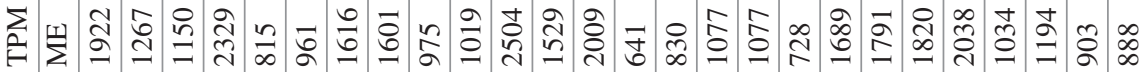

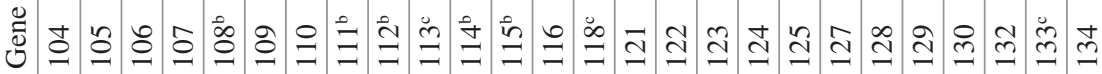

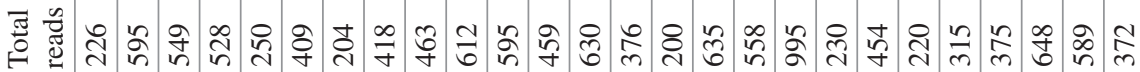

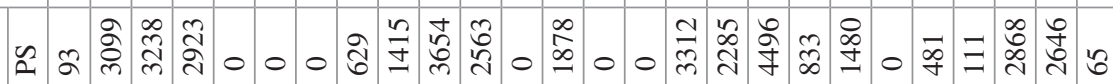

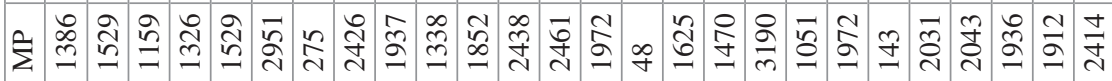

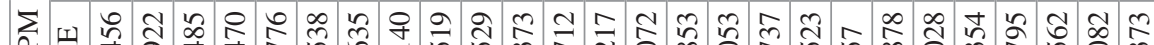

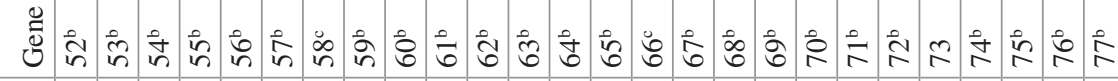

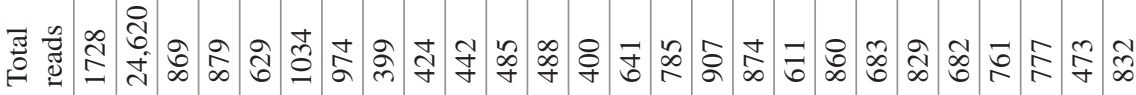

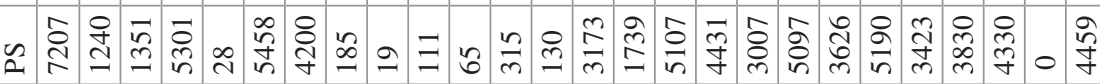
范

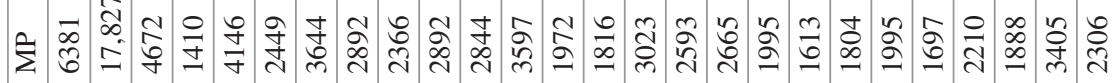

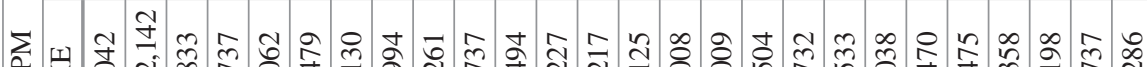

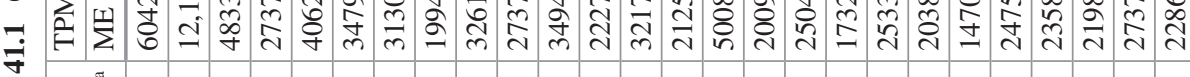

产

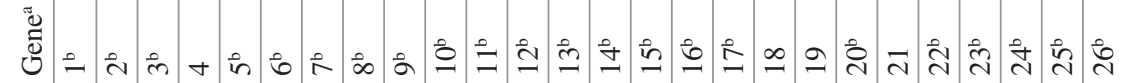




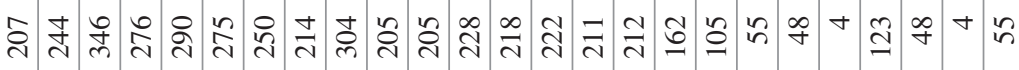

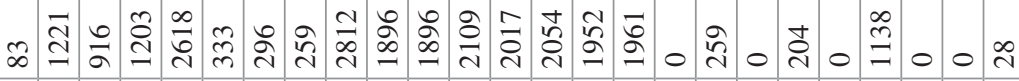

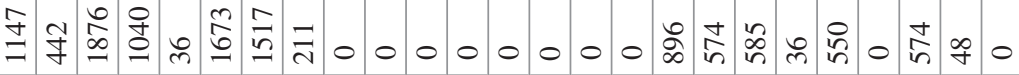

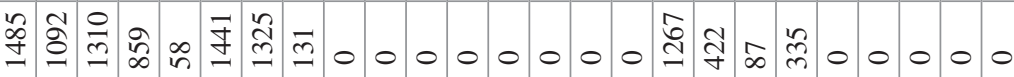

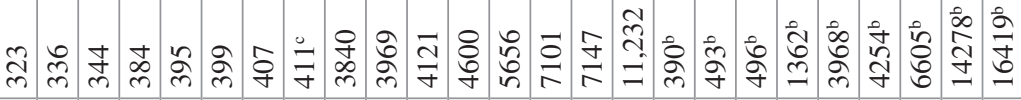

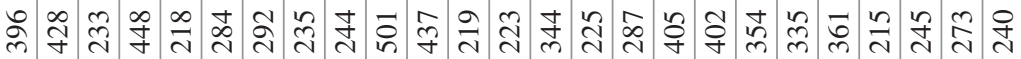

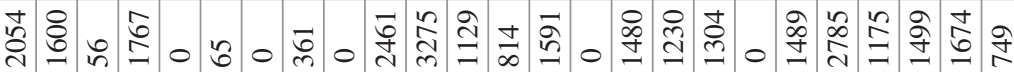

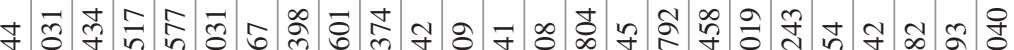

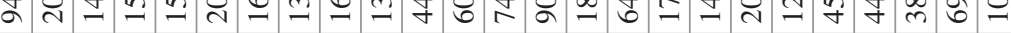

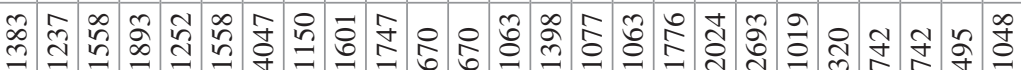

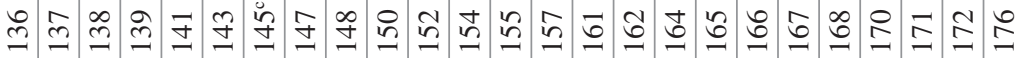

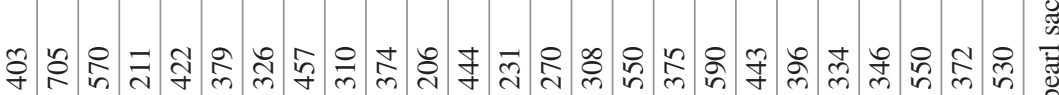

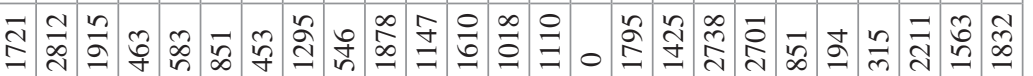

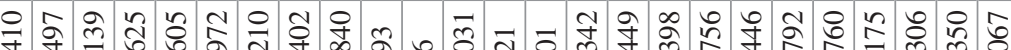

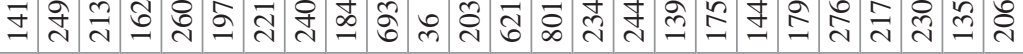

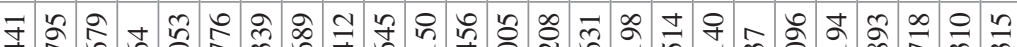

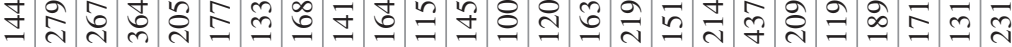

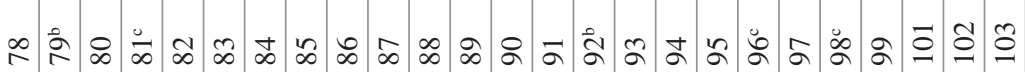

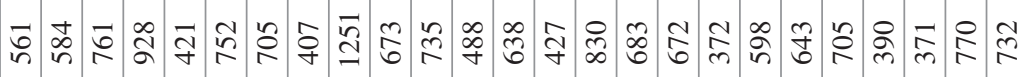

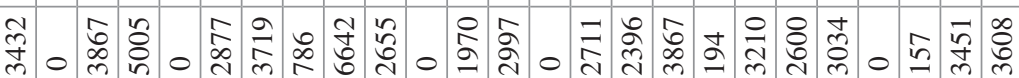

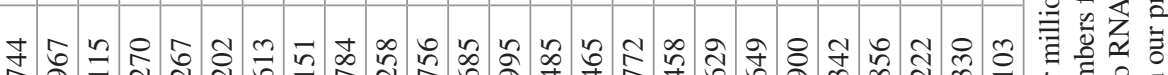

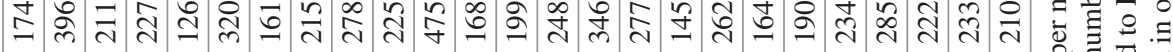

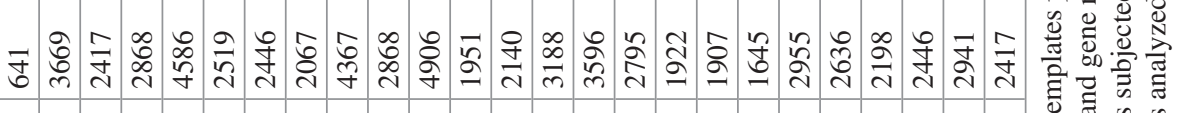

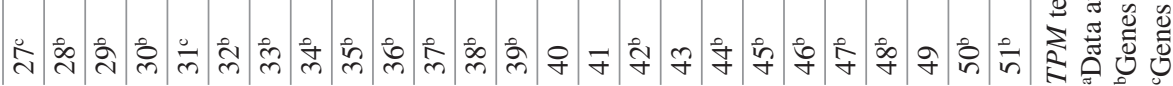


Table 41.2 Appearances of the inner surface of shells injected with dsRNAs of the subject genes

\begin{tabular}{|c|c|c|c|c|c|c|c|c|}
\hline Gene $^{a}$ & Prismatic & Nacreous & Gene & Prismatic & Nacreous & Gene & Prismatic & Nacreous \\
\hline 1 & $\mathrm{n}$ & $\mathrm{a}$ & 39 & $\mathrm{a}$ & $\mathrm{a}$ & 79 & $\mathrm{a}$ & $\mathrm{a}$ \\
\hline 2 & $\mathrm{a}$ & $\mathrm{a}$ & 42 & $\mathrm{n}$ & $\mathrm{a}$ & 92 & $\mathrm{a}$ & $\mathrm{a}$ \\
\hline 3 & $\mathrm{a}$ & $\mathrm{a}$ & 44 & $\mathrm{n}$ & $\mathrm{a}$ & 108 & $\mathrm{n}$ & $\mathrm{a}$ \\
\hline 5 & $\mathrm{n}$ & $\mathrm{a}$ & 45 & $\mathrm{n}$ & $\mathrm{a}$ & 111 & $\mathrm{n}$ & $\mathrm{a}$ \\
\hline 6 & a & a & 46 & $\mathrm{a}$ & $\mathrm{a}$ & 112 & $\mathrm{n}$ & $\mathrm{a}$ \\
\hline 7 & $\mathrm{a}$ & $\mathrm{a}$ & 47 & $\mathrm{n}$ & $\mathrm{a}$ & 114 & $\mathrm{a}$ & $\mathrm{n}$ \\
\hline 8 & $\mathrm{a}$ & $\mathrm{a}$ & 48 & $\mathrm{n}$ & $\mathrm{a}$ & 115 & $\mathrm{n}$ & $\mathrm{n}$ \\
\hline 9 & $\mathrm{n}$ & $\mathrm{a}$ & 50 & $\mathrm{n}$ & $\mathrm{a}$ & 390 & $\mathrm{n}$ & $\mathrm{n}$ \\
\hline 10 & $\mathrm{a}$ & $\mathrm{a}$ & 51 & $\mathrm{n}$ & $\mathrm{a}$ & 493 & $\mathrm{n}$ & $\mathrm{n}$ \\
\hline 11 & $\mathrm{a}$ & $\mathrm{a}$ & 52 & $\mathrm{n}$ & $\mathrm{a}$ & 496 & $\mathrm{n}$ & $\mathrm{n}$ \\
\hline 12 & $\mathrm{n}$ & $\mathrm{a}$ & 53 & $\mathrm{n}$ & $\mathrm{a}$ & 1362 & $\mathrm{n}$ & $\mathrm{n}$ \\
\hline 13 & $\mathrm{a}$ & $\mathrm{a}$ & 54 & $\mathrm{n}$ & $\mathrm{n}$ & 3968 & $\mathrm{n}$ & $\mathrm{n}$ \\
\hline 14 & $\mathrm{a}$ & $\mathrm{a}$ & 55 & $\mathrm{n}$ & $\mathrm{a}$ & 4254 & $\mathrm{n}$ & $\mathrm{n}$ \\
\hline 15 & $\mathrm{a}$ & $\mathrm{a}$ & 56 & $\mathrm{n}$ & $\mathrm{a}$ & 6605 & $\mathrm{n}$ & $\mathrm{a}$ \\
\hline 16 & $\mathrm{n}$ & $\mathrm{a}$ & 57 & $\mathrm{n}$ & $\mathrm{a}$ & 14,278 & $\mathrm{n}$ & $\mathrm{n}$ \\
\hline 17 & $\mathrm{n}$ & $\mathrm{a}$ & 59 & $\mathrm{a}$ & $\mathrm{a}$ & 16,419 & $\mathrm{n}$ & $\mathrm{n}$ \\
\hline 20 & $\mathrm{n}$ & $\mathrm{a}$ & 60 & $\mathrm{n}$ & $\mathrm{a}$ & $27^{b}$ & $\mathrm{a}$ & $\mathrm{a}$ \\
\hline 22 & $\mathrm{n}$ & $\mathrm{a}$ & 61 & $\mathrm{n}$ & $\mathrm{n}$ & $31^{\mathrm{b}}$ & $\mathrm{a}$ & $\mathrm{a}$ \\
\hline 23 & $\mathrm{a}$ & $\mathrm{a}$ & 62 & $\mathrm{n}$ & $\mathrm{a}$ & $58^{\mathrm{b}}$ & $\mathrm{n}$ & $\mathrm{a}$ \\
\hline 24 & $\mathrm{n}$ & $\mathrm{a}$ & 63 & $\mathrm{n}$ & $\mathrm{a}$ & $66^{\mathrm{b}}$ & $\mathrm{n}$ & $\mathrm{a}$ \\
\hline 25 & $\mathrm{n}$ & $\mathrm{a}$ & 64 & $\mathrm{n}$ & $\mathrm{n}$ & $81^{\mathrm{b}}$ & $\mathrm{a}$ & $\mathrm{a}$ \\
\hline 26 & $\mathrm{n}$ & $\mathrm{a}$ & 65 & $\mathrm{n}$ & $\mathrm{a}$ & $96^{b}$ & $\mathrm{a}$ & $\mathrm{a}$ \\
\hline 28 & $\mathrm{n}$ & $\mathrm{a}$ & 67 & $\mathrm{n}$ & $\mathrm{n}$ & $98^{\mathrm{b}}$ & $\mathrm{a}$ & $\mathrm{a}$ \\
\hline 29 & $\mathrm{a}$ & $\mathrm{a}$ & 68 & $\mathrm{n}$ & $\mathrm{a}$ & $113^{\mathrm{b}}$ & $\mathrm{n}$ & $\mathrm{a}$ \\
\hline 30 & $\mathrm{n}$ & $\mathrm{a}$ & 69 & $\mathrm{n}$ & $\mathrm{a}$ & $118^{\mathrm{b}}$ & $\mathrm{n}$ & $\mathrm{a}$ \\
\hline 32 & $\mathrm{n}$ & $\mathrm{a}$ & 70 & $\mathrm{n}$ & $\mathrm{a}$ & $133^{b}$ & $\mathrm{n}$ & $\mathrm{a}$ \\
\hline 33 & $\mathrm{n}$ & $\mathrm{a}$ & 71 & $\mathrm{n}$ & $\mathrm{n}$ & $145^{\mathrm{b}}$ & $\mathrm{n}$ & $\mathrm{a}$ \\
\hline 34 & $\mathrm{n}$ & $\mathrm{a}$ & 72 & $\mathrm{n}$ & $\mathrm{n}$ & $194^{\mathrm{b}}$ & a & $\mathrm{a}$ \\
\hline 35 & $\mathrm{n}$ & $\mathrm{a}$ & 74 & $\mathrm{n}$ & $\mathrm{a}$ & $200^{\mathrm{b}}$ & $\mathrm{n}$ & $\mathrm{a}$ \\
\hline 36 & $\mathrm{a}$ & $\mathrm{a}$ & 75 & $\mathrm{n}$ & $\mathrm{a}$ & $411^{b}$ & $\mathrm{n}$ & $\mathrm{a}$ \\
\hline 37 & $\mathrm{n}$ & $\mathrm{a}$ & 76 & $\mathrm{n}$ & $\mathrm{n}$ & & & \\
\hline 38 & $\mathrm{n}$ & $\mathrm{a}$ & 77 & $\mathrm{n}$ & $\mathrm{a}$ & & & \\
\hline
\end{tabular}

$n$ normal appearance, $a$ abnormal appearance

${ }^{\mathrm{a}}$ Gene numbers from Kinoshita et al. (2011)

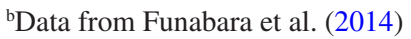

are required to discuss their function. To determine the full-length sequences, it is reasonable that we choose genes in descending order of the numbers of their reads in the EST data. We can also search the genome database for their gene models by BLAST searching using the EST sequence data (Takeuchi et al. 2012).

Many studies on shell formation-related proteins have focused on those secreted from mantle tissues into shells. This way is incapable of analyzing regulatory 


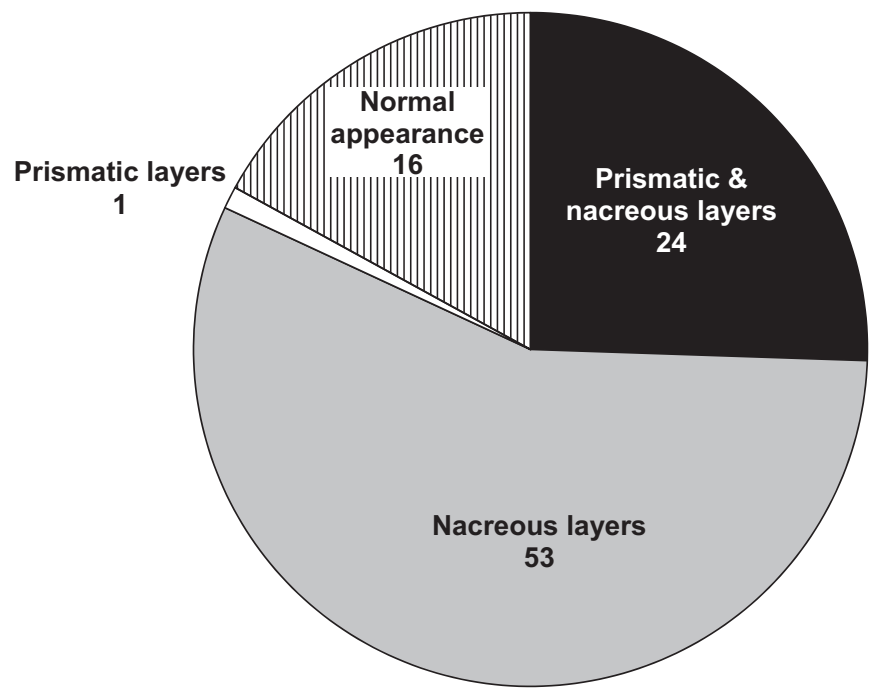

Fig. 41.1 The numbers of individuals having normal and abnormal appearances on the inner surface of the shells of the Japanese pearl oysters Pinctada fucata subjected to the RNAi experiments as observed by SEM. "Prismatic and nacreous layers," "nacreous layers," "prismatic layers," and "normal appearances" indicate individuals having abnormal appearances on "both the prismatic and nacreous layers," "only on the nacreous layers," "only on the prismatic layers," and "normal appearances" on the shell inner surface, respectively. Numerals indicate the numbers of the genes

pathways to form shells. We found in our previous study that some shell formationrelated genes encoded proteins lacking a signal peptide, suggesting that such cytoplasmic proteins function in shell formation together with secretory ones (Funabara et al. 2014). We have not determined the full-length sequences for the newly identified 64 genes to be involved in shell formation yet. They may contain cytoplasmic proteins which function in shell formation. The combination of transcriptome and knockdown analyses would give us some useful information on the shell formation processes from genes to shells.

\section{References}

Funabara D, Ohmori F, Kinoshita S, Koyama H, Mizutani S, Ota A, Osakabe Y, Nagai K, Maeyama K, Okamoto K, Kanoh S, Asakawa S, Watabe S (2014) Novel genes participating in the formation of prismatic and nacreous layers in the pearl oyster as revealed by their tissue distribution and RNA interference knockdown. PLoS One 9:e84706

Kinoshita S, Wang N, Inoue H, Maeyama K, Okamoto K, Nagai K, Kondo H, Hirono I, Asakawa S, Watabe S (2011) Deep sequencing of ESTs from nacreous and prismatic layer producing tissues and a screen for novel shell formation-related genes in the pearl oyster. PLoS One 6:e21238 
Miyamoto H, Miyashita T, Okushima M, Nakano S, Morita T, Matsushiro A (1996) A carbonic anhydrase from the nacreous layer in oyster pearls. Proc Natl Acad Sci U S A 93:9657-9660

Suzuki M, Saruwatari K, Kogure T, Yamamoto Y, Nishimura T, Kato T, Nagasawa H (2009) An acidic matrix protein, Pif, is a key macromolecule for nacre formation. Science 325:1388-1390

Takeuchi T, Kawashima T, Koyanagi R, Gyoja F, Tanaka M, Ikuta T, Shoguchi E, Fujiwara M, Shinzato C, Hisata K, Fujie M, Usami T, Nagai K, Maeyama K, Okamoto K, Aoki H, Ishikawa T, Masaoka T, Fujiwara A, Endo K, Endo H, Nagasawa H, Kinoshita S, Asakawa S, Watabe S, Satoh N (2012) Draft genome of the pearl oyster Pinctada fucata: a platform for understanding bivalve biology. DNA Res 19:117-130

Open Access This chapter is licensed under the terms of the Creative Commons Attribution 4.0 International License (http://creativecommons.org/licenses/by/4.0/), which permits use, sharing, adaptation, distribution and reproduction in any medium or format, as long as you give appropriate credit to the original author(s) and the source, provide a link to the Creative Commons license and indicate if changes were made.

The images or other third party material in this chapter are included in the chapter's Creative Commons license, unless indicated otherwise in a credit line to the material. If material is not included in the chapter's Creative Commons license and your intended use is not permitted by statutory regulation or exceeds the permitted use, you will need to obtain permission directly from the copyright holder.

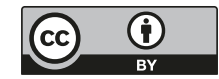

